\author{
Natalia Walkowiak \\ Uniwersytet Jana Kochanowskiego w Kielcach \\ ORCID: 0000-0002-6716-4523 \\ Przemysław Ciszek \\ Uniwersytet Jana Kochanowskiego w Kielcach \\ ORCID: 0000-0003-0203-3810
}

\title{
Sprawozdanie z X Ogólnopolskiej Konferencji Medialnej „Media w przestrzeni społecznej - przestrzeń spoleczna w mediach". Bielsko-Biała, 13 grudnia 2019
}

W dniu 13 grudnia 2019 roku w Bielsku-Białej odbyła się Jubileuszowa X Edycja Ogólnopolskiej Konferencji Medialnej „Media w przestrzeni społecznej - przestrzeń społeczna w mediach". Organizatorami byli Wydział Zarządzania i Transportu, Wydział Nauk Ekonomicznych i Społecznych, Wydział Humanistyczno-Społeczny, Katedra Polonistyki Akademii Techniczno-Humanistycznej w Bielsku-Białej, Wydział Nauk Humanistycznych i Społecznych, Katedra Socjologii i Historii Wojskowości Akademii Marynarki Wojennej im. Bohaterów Westerplatte w Gdyni oraz Wydział Humanistyczny, Katedra Dziennikarstwa i Komunikacji Społecznej Uniwersytetu Jana Kochanouskiego w Kielcach. Konferencja odbyła się pod patronatem czasopisma naukouego ATH - „Media i Społeczeństuo”. Patronat medialny objęli: „Gazeta Wyborcza”, „Dziennik Zachodni”, „Gazeta Beskidzka” i bielsko.info. Miejscem konferencji był Kampus Akademii Techniczno-Humanistycznej.

Konferencja rozpoczęła się sesją plenarną. Otwierający spotkanie profesor ATH dr hab. Marek Bernacki podkreślił, że jubileuszowa edycja przyciągnęła rekordową liczbę Uczestników (Organizatorzy otrzymali ponad 40 zgłoszeń, odbyło się 5 sesji równoległych ${ }^{1}$ ). We wprowadzeniu profesor mówił o epoce przestrzeni i symultaniczności, odwołując się między innymi do Olgi Tokarczuk, zadał także pytania o przestrzeń i cyberprzestrzeń. Doktor hab. Katarzyna Gajlewicz-Korab z Uniwersytetu Warszauskiego przedstawiła referat pt. „Problemy uspółczesnej telewizji francuskiej. Cyfryzacja, nowe technologie, nowe potrzeby odbiorców". Zwróciła uwagę na preferencje dzisiejszych odbiorców i zmiany, jakie zachodzą na francuskim rynku telewizyjnym.

\footnotetext{
${ }^{1}$ W sprawozdaniu nie omówiono sesji IV, ponieważ autorzy sprawozdania nie mogli wziąć u niej udziału.
} 
Profesor UJK dr hab. Olga Dąbrowska-Cendrouska zaprezentowała temat: „Segment magazynów true story u Polsce i Wielkiej Brytanii. Analiza na podstawie »Chwili dla Ciebie« i »Take a Break«". Autorka skupiła się na omówieniu zawartości magazynów, preferencji czytelników, zwróciła także uwagę na strukturę własności tego typu prasy i ich sprzedaż. Wystąpienie dr. Tomasza Bielaka z Akademii Techniczno-Humanistycznej w Bielsku-Białej zatytułowane „Społecznie uśpieni - o (pozornie) milczących użytkownikach mediów" dotyczyło jego 10-letnich badań i obserwacji. Autor, mówiąc o uyobcowaniu, odnosił się głównie do użytkowników Facebooka. Magister Monika Plaskova uygłosiła referat: „Zwierciadło Zaolzia czyli media polonijne w Republice Czeskiej”. Przedstawiła media polonijne, ich zawartość, a także problemy, zaznaczając istotną rolę, jaką odgrywają dla Polaków, mieszkających na terenie Czech. Sesję plenarną zakończyła ciekawa dyskusja odnosząca się do poszczególnych referatów.

Sesji II przewodniczyła dr hab. Katarzyna Gajlewicz-Korab (UW). Wystąpiło na niej sześcioro prelegentów. Doktor Ewelina Tyc reprezentująca Uniwersytet Śląski przedstawiła referat pt. „Medialny wizerunek w tradycyjnym wydaniu (na przykładzie »Nieautoryzowanej autobiografii« Kuby Wojewódzkiego)". Na początku krótko przedstawiła syluetkę Jakuba Wojewódzkiego. Następnie skoncentrowała się na zawartości autobiografii, która okazała się w dużej mierze zręczną kompilacją wcześniejszych tekstów autora oraz wypowiedzi gości jego talk-show. Zuróciła także uwagę, że tekst przypomina strumień świadomości i jest bardzo chaotyczny. Innym ciekawym wystąpieniem był referat mgr Anny Skibińskiej z Uniwersytetu Wrocłauskiego pt. „Medialne spojrzenie na (po)serialową rzeczywistość za Bugiem wizerunek Wołodymyra Zełenskiego na portalu Kresy.pl". Zanalizowała artykuły dotyczące obecnego prezydenta Ukrainy zamieszczane na uspomnianym portalu od 1 stycznia 2019 do 20 listopada 2019. Okazało się, że do momentu uyborów określano go zazwyczaj jako aktora i showmana. Po uygranej w wyborach zmieniono nastawienie i zaprzestano stosowania takich słów.

Równolegle odbywała się Sesja III, której przewodniczyła prof. UJK dr. hab. Olga Dąbrouska-Cendrouska. Jako pierwsza wystąpiła dr Katarzyna Sanak-Kosmouska, która mówiła o Marketingu w mediach spotecznościowych - między reklama a manipulacją. Zuróciła szczególną uwagę na narzędzia wywierania upływu na konsumenta w mediach społecznościouych. Magister Natalia Walkowiak z Uniwersytetu Jana Kochanouskiego w Kielcach przedstawiła temat: „Prasa kobieca we Francji w XXI wieku". Skupiła się na najlepiej sprzedających się magazynach w 2018. Zaznaczyła także rolę, jaką odgrywa reklama w czasopismach adresowanych do żeńskiego odbiorcy. Referat mgr Żanety Wełny z Uniwersytetu Papieskiego Jana Pawła II w Krakowie „Polityk aktywny - polityk interaktywny” dotyczył obecności liderów politycznych w mediach społecznościowych na przykładzie polskiej kampanii parlamentarnej 2019. Autorka omówiła działania przedstawicieli (Mateusza Morawieckiego, Grzegorza Schetyny, Janusza Korwina-Mikkego, Wladysława Kosiniaka-Kamysza i Włodzimierza Czarzastego) najważniejszych partii politycznych między innymi na Facebooku, Instagramie czy Twitterze. 
Sesja V odbyła się pod przewodnictuem dr Anny Foltyniak-Pękali. Referaty zaprezentowało na niej sześcioro dyskutantów. Magister Agnieszka Zielińska (Uniwersytet Ekonomiczny w Katowicach/Akademia Techniczno-Humanistyczna w Bielsku-Białej) przedstawiła interesujący referat pt. „Skuteczne porozumiewanie się w zespołach rozproszonych". Zuróciła w nim uwagę na aspekt relacji międzyludzkich i odpowiedniego podejścia do pracouników pracujących zdalnie z różnych miejsc. Magister Wojciech Śmiech (Katolicki Uniwersytet Lubelski Jana Pawła II) w swoim wystąpieniu pt. „Wpływ mediów na funkcjonowanie klubu sportowego” skupił się na tym, jak komunikacja w mediach tradycyjnych oraz społecznościouych upływa na działanie klubów piłkarskich. Stwierdzil, że oddziaływanie to może być wielopłaszczyznowe i może mieć także wymierne skutki finansowe. Magister Przemysław Ciszek (Uniwersytet Jana Kochanouskiego w Kielcach) zaprezentował referat pt. „Komunikacja na streamach z gier wideo", przedstawiając różne kanały komunikacyjne, w ramach których są przekazywane informacje $w$ transmisjach na żywo w serwisach YouTube i Twitch. Omówił także, w jaki sposób streamerzy porozumiewają się ze suoimi widzami.

Oficjalne zakończenie konferencji odbyło się o 16.00. Wystąpienie podsumourjące wygłosiła dr Katarzyna Piątek z ATH. Owocem obrad będzie monografia wydana przez ATH w Bielsku-Białej oraz specjalny tom czasopisma „Media i Społeczeństwo”. 